\title{
SOSIALISASI e-ARSIP SEBAGAI PENGOLAHAN DATA DINAS LUAR PADA KANTOR KESEHATAN PELABUHAN PEKANBARU
}

\author{
Bayu Febriadi ${ }^{1}$, Pandu Pratama Putra ${ }^{2}$, \\ ${ }^{1,2}$ Universitas Lancang Kuning, Pekanbaru, Indonesia \\ bayufebriadi9@gmail.com ${ }^{1}$,pandupratamaputra@unilak.ac.id ${ }^{2}$
}

\begin{abstract}
Abstrak: Kantor Kesehatan Pelabuhan (KKP) Pekanbaru merupakan Kantor pemerintahan yang bergerak di bidang kesehatan khususnya mengenai lingkungan. Dalam kegiatan dinas luar seperti surveilans kesehatan kapal, surveilans kesehatan masyarakat, bimbingan teknis, pengawasan dokumen kesehatan, surveilans faktor penyakit tidak menular pada kantor cabang kesehatan pelabuhan di provinsi riau seperti Kantor Selat Panjang, Kantor Tanjung Buton, Kantor Siak Sri Indrapura, Kantor Buatan, Kantor Sei. Duku, Kantor Kampung Dalam, kantor KKP Bangkinang dan Kantor Kuantan Singingi. Adapun pengolahan data masih belum teritegrasi dengan baik sehingga susah dalam melakukan pendataan dokumen dan informasi dari hasil kegiatan dinas luar, sementara pengadaan komputer dan sumber daya ada. Dan kegiatan ini selalu dilakukan tiap kegiatan sehingga diperlukan sebuah sistem yang dapat mengontrol data-data kegiatan dan dokumen yang dibutuhkan dalam pembuatan laporan kegiatan. Hal inilah yang menjadi ketertarikan penulis untuk membantu permasalahan yang dihadapi karyawan di Kantor Kesehatan Pelabuhan Pekanbaru supaya lebih efisien dalam menjalankan kegiatan. Relational Database management System (RDBMS) adalah kumpulan data yang disimpan secara sistematis di dalam komputer yang dapat diolah atau dimanipulasi menggunakan perangkat lunak (program aplikasi) untuk menghasilkan informasi. Dengan memanfaatkan teknologi informasi RDBMS sehingga aplikasi berbasis online dapat diakses kapan dan dimana saja dari tempat karyawan melakukan kegiatan dinas luar dapat langsung meng-input dan pengolahan data untuk penyajian informasi yang lebih cepat ke kantor pusat pelabuhan pekanbaru dan dengan pendekatan metode System development Life Cycle (SDLC) dalam penyelesaian masalah kegiatan dinas luar, sehingga diharapkan pengolahan data dapat terintegrasi dan lebih efisien dalam pendataan informasi, dengan demikian diharapkan dapat membantu pihak kantor dalam pengolahan data yang lebih efisien dan lebih aman khususnya dalam pengolahan data dinas luar pada kantor kesehatan pelabuhan pekanbaru.
\end{abstract}

Kata Kunci: e-Arsip, RDBMS, Kantor Kesehatan Pelabuhan Pekanbaru

\begin{abstract}
Pekanbaru Port Health Office (KKP) is a government office engaged in the health sector, especially regarding the environment. In external service activities such as ship health surveillance, public health surveillance, technical guidance, supervision of health documents, surveillance of noncommunicable disease factors at port health branch offices in Riau province such as the Selat Panjang Office, Tanjung Buton Office, Siak Sri Indrapura Office, Artificial Office, Sei's office. Duku, the Kampung Dalam office, the Bangkinang KKP office and the Kuantan Singingi office. The data processing is still not well integrated so that it is difficult to collect data on documents and information from the results of external service activities, while the procurement of computers and resources is available. And this activity is always carried out every activity so that a system is needed that can control the activity data and documents needed in making activity reports. This is the author's interest to help the problems faced by employees at the Pekanbaru Port Health Office to be more efficient in carrying out activities. Relational Database Management System (RDBMS) is a collection of data stored systematically in a computer that can be processed or manipulated using software (application programs) to generate information. By utilizing RDBMS information technology so that online-based applications can be accessed anytime and anywhere from where employees carry out external service activities, they can directly input and process data for faster information presentation to the Pekanbaru port head office and with the System Development Life Cycle method approach. $S D L C)$ in solving problems of external service activities, so it is hoped that data processing can be integrated and more efficient in data collection information, thus it is hoped that it can help the office
\end{abstract}


in processing data more efficiently and more safely, especially in processing external service data at the Pekanbaru port health office.

Keywords: e-Archive, RDBMS, Pekanbaru Port Health Office

\section{Pendahuluan}

Sistem informasi berbasis komputer sangat berpengaruh pesat dalam dunia kerja, begitu juga halnya sistem informasi berbasis web dimanfaatkan sebagai sarana peningkatan informasi. Pemanfaatan tersebut akan mempermudah suatu pekerjaan seperti halnya pengolahan data lebih cepat, keputusan yang akan diambil lebih tepat, menghemat waktu dan biaya. Selain itu, sistem informasi yang berbasis web juga dapat menjadi sarana promosi yang efisien dan sumber informasi yang dapat diakses oleh pengguna internet yang semakin lama semakin luas. dimana pemanfaatan sistem informasi berbasis komputer sangat membantu dalam kegiatan sehari-hari.

Kantor Kesehatan Pelabuhan Pekanbaru merupakan Kantor pemerintahan yang bergerak dibidang kesehatan khususnya mengenai lingkungan. Dalam kegiatan dinas luar seperti surveilans kesehatan kapal, surveilans kesehatan masyarakat, bimbingan teknis, pengawasan dokumen kesehatan, surveilans faktor penyakit tidak menular pada kantor cabang kesehatan di provinsi riau seperti Kantor Selat Panjang, Kantor Tanjung Buton, Kantor Siak Sri Indrapura, Kantor Buatan, Kantor Sei. Duku, Kantor Kampung Dalam. Dan kegiatan ini selalu dilakukan tiap adanya kegiatan sehingga diperlukan sebuah sistem yang dapat mengontrol data-data kegiatan dinas luar dan dokumen yang dibutuhkan dalam pembuatan laporan kegiatan.

Hal inilah yang menjadi ketertarikan penulis untuk membantu permasalahan yang dihadapi karyawan di Kantor Kesehatan Pelabuhan Pekanbaru supaya lebih memudahkan dalam menjalankan kegiatan dinas luar. Setelah diadakan diskusi langsung peneliti dengan pihak karyawan di kantor kesehatan pelabuhan pekanbaru, disimpulkan mereka membutuhkan pelatihan bagi karyawan dalam pengolahan data elektronik sebagai media yang dapat digunakan dalam pengolahan data dinas luar. Mereka berharap dengan adanya pemanfaatan aplikasi pengolahan berbasis data dan online dapat menyelesaikan permasalahan pada kegiatan dinas luar di kantor kesehatan pelabuhan pekanbaru.

Setelah dilakukan analisa di kantor kesehatan pelabuhan pekanbaru penulis menemukan beberapa permasalahan yang harus segera dibenahi diantaranya:

a) Belum adanya sistem yang dapat membantu pengolahan data kegiatan dinas luar pada kantor kesehatan pelabuhan pekanbaru sehingga menyulitkan bagi karyawan dalam pengolahan data dan penyajian informasi.

b) Masih minimnya aspek pengetahuan karyawan kantor kesehatan pelabuhan pekanbaru dalam penggunaan komputer, Sementara kebutuhan penggunaan komputer sangat diperlukan dalam pengolahan data menjadi lebih baik khususnya dalam mengintegrasikan data dinas luar.

c) Pengolahan data masih belum terintegrasi dengan baik sehingga susah dalam melakukan pendataan informasi, sementara pengadaan komputer dan sumber daya ada. 
Berkaitan dengan hal tersebut, maka sangat diperlukan adanya sistem yang dapat membantu semua permasalahan dalam pengolahan data dinas luar dengan memanfaatkan teknologi informasi sebagai pusat pengolahan data sehingga sistem dapat langsung diakses dari kantor cabang. Maka diperlukan sebuah bentuk permodelan sistem yang baru. Permodelan ini nantinya akan dikembangkan dalam bentuk sistem yang nantinya bisa diterapkan di Kantor Kesehatan Pelabuhan Pekanbaru.

\section{Metode}

Kegiatan PKM ini dilakukan kapada dua mitra yaitu Staf pengelola/petugas kearsipan pada cabang kantor Sei. Duku dan Cabang Kampung Dalam di Kantor Kesehatan Pelabuhan Pekanbaru.

\section{a. Pelatihan Penyuluhan tentang e-Arsip dalam digital dokumentasi}

Kegiatan pelatihan yang dilakukan pengusul kepada mitra PKM adalah menstransfer informasi tentang tata cara bagaimana pemahaman Arsip dan sistem pengarsipan sesuai dengan standar pengelolaan arsip. Pemberian pelayanan kepada masyarakat dan memudahkan staff itu sendiri, faktor-faktor yang mempengaruhi kualitas pelayanan kepada masyarakat antara lain adalah staf/karyawan itu sendiri karena mereka merupakan ujung tombak dari pada pelaksanaan sistem pengarsipan yang baik, dalam kegiatan PKM ini akan dilakukan paktek mendigitalkan arsip, sistem pengelolaan arsip dan pengarsipan. Pada saat pengusul melakukan survey di lokasi PKM diketahui bahwa para staff belum banyak yang paham bagaimana mendigitalkan arsip dan mengelola dan sistem pengarsipan yang baik. Mereka masih menganggap sepele terhadap arsip yang penting, namun setelah mereka ataupun masyarakat membutuhkan akan arsip tersebut para staf baru sibuk mencari dimana mereka letakkan surat-surat tersebut. Rata-rata mereka tamatan Ilmu Kesehatan. Maka dari itu pengusul akan mentransfer informasi kepada mitra dengan mengadakan diskusi tentang pentingnya sebuah arsip dikelola dengan baik, kemudian bagaimana mendigtalkaan arsip, hanya cukup dengan kemauan yang kuat semuanya dapat dilakukan. Materinya adalah:

1. Pemahaman Database

2. Arsip Digital

3. Sistem Manajemen Arsip data Dinas Luar

4. Peralatan dan Perlengkapan dalam kegiatan e-Arsip dokumen

5. Komputerisasi Arsip dan Pemanfaatan e-Arsip.

\section{b. Pelatihan untuk pemahaman e-Arsip}

Dalam pelatihan untuk pemahaman ini mitra di beri pengetahuan tentang Apa itu e-Arsip dan Kearsipan, bagaimana mengelola arsip digital dari arsip itu diciptakan, didistribusikan, yang diperagakan dan dipresentasikan serta diberikan oleh tim Universitas Lancang Kuning kepada mitra kemudian dilakukan juga sesi tanya jawab. Mitra dilatih melakukan pemahaman dahulu terhadap sistem Arsip dan SIM e-Arsip agar nantinya mitra tidak kesulitan dalam sesi simulasi. 


\section{c. Pratikum Penggunaan Aplikasi e-Arsip}

Pada tahapan ini peserta diajak untuk mempraktekan dan mencoba bagaimana mendigitalkan arsip dan apa yang dilakukan dalam mengelola arsip menggunakan komputer mulai dari arsip itu diciptakan, didistribusikan, sampai arsip itu disimpan dengan sistem e-Arsip berbasis teknologi informasi yang benar, masing-masing peserta diberi kesempatan untuk dapat mempraktekkannya, sehingga instruktur dapat melihat sampai dimana kemampuan yang sudah dimiliki oleh staff tersebut.

\section{d. Evaluasi hasil}

Setelah pelatihan juga akan disebar angket untuk melihat pencapaian hasil pelatihan. Evaluasi hasil dapat diketahui dengan membandingkan hasil pretest dan postest dari kuesioner yang telah diisi oleh mitra, kemudian diolah untuk dapat disimpulkan

\section{Hasil dan Pembahasan}

Kegiatan ini dilaksanakan di ruang pertemuan pada Kantor pada tanggal 12 November 2021, yang dihadiri oleh 15 peserta, berdasarkan kegiatan yang telah dilaksanakan, beberapa hasil telah diperoleh.

Pada tahap pertama, peserta dibagikan kuesioner pretest untuk diisi peserta setelah itu Tim PKM menjelaskan teori tentang Pengarsipan dan Arsip Digital serta arahan cara bagaimana melakukan pembuatan arsip digital, sehingga peserta memperoleh pemahaman tentang konsep dasar pengarsipan dokumen.

Pada tahap kedua, peserta diajak untuk pemahaman terhadap materi yang telah disampaikan dan dipresentasikan oleh Tim Pengabdian, kemudian pada sesi ini juga dibuka sesi tanya jawab terlihat semua peserta antusias untuk bertanya bahkan tim sedikit agak kerepotan dalam melayani yang bertanya mengenai kesulitan yang selamaini mereka hadapi dilapangan untuk mengolahsurat masuk dan keluar sebab selama ini masih menggunakan hard copy yang diarsipkan di lemari arsip. Kemudian Tim Pengabdian menjelaskan salah satunya yaitu dengan berlatih dan praktek sesering mungkin dan dengan sebaik-baiknya,akan mendapatkan hasil yang bagus dan mereka nantinya mampu tanpa harus melihat buku panduan lagi, sehingga dengan demikian mereka akan mampu untuk membuat arsip digital dengan mudah.

Pada tahap terakhir, setelah peserta memiliki ketrampilan dalamproses membuat arsip digital, tim meminta kepada semua peserta yang ikut agar dapat menerapkan ilmunya dan menularkan kepada teman-teman yang tidak bisa ikut pada saat ini.

Setelah peserta memahami dasar-dasar teknik melakukan proses mendigitalkan arsip maka selanjutnya diharapkan dapat melakukan pengolahan arsip, pada tahap ini peserta diminta bagi yang sudah paham untuk dapat memberitahukan kepada peserta lain yang belum begitu mengerti tentang materi yang telah dibahas. 
Sesi berikutnya adalah sesi praktik melakukan bagaimana scan surat surat dilakukan dengan menggunakan scanner, setiap peserta diberi kesempatan untuk mempraktekkan langsung kemudian dilanjutkan dengan sharing sesama peserta lainnya.

Sesi terakhir adalah sesi tanya jawab. Pada sesi ini peserta diberikan kesempatan untuk menanyakan dan menanggapi mengenai teori yang telah dipaparkan sebelumnya. Peserta terlihat antusias untuk menanyakan hal-hal yang berkaitan dengan tema pelatihan. Menurut mereka hal ini merupakan sesuatu yang menarik, terutama mengenai kegiatan praktik langsung dipandu dan disimulasikan.

Terakhir tim menyampaikan kepada peserta bahwa ini harus dilatih secara terus menerus untuk memperoleh hasil yang maksimal, jadi suatu pelatihan tidak akan berhasil dan kelihatan hasilnya jika tidak dibarengi dengan kemauan pada masing-masing peserta untuk mau empraktekkan dan menerapkan di linhgkungan kerja. Untuk itu, peserta diberi keyakinan bahwa hasil yang memuaskan tidak akan muncul begitu saja dengan mudah, tetapi diperlukan konsistensi dan keyakinan bahwa sesederhana apapun kegiatan yang dilakukan jika diikuti dengan keyakinan yang kuat maka akan memberikan hasil yang memuaskan.

Evaluasi, ini diperoleh hasil olahan kusioner yakni dengan memberikan kuesioner pada peserta sebelum dan sesudah pelatihan, kemudian dari jawaban kuesioner yang diberikan akan kelihatan perbandingan pengetahuan perserta sebelum dan sesudah pelatihan, lalu ditarik kesimpulan dari hasil yang diperoleh, dari hasil kuisioner tersebut dapat diketahui bagaimana pemahaman peserta terhadap materi yang diberikan selama pelatihan.

Untuk lebih jelasnya dapat dilihat hasil rekapitulasi jawaban responden:

Tabel 1. Hasil Rekapitulasi Kuesioner pre test

\begin{tabular}{|c|c|c|c|c|}
\hline No & Item Pertanyaan & Benar & Salah & Kosong \\
\hline 1. & $\begin{array}{l}\text { Apa sebelumnya sudah pernah mendapatkan pelatihan } \\
\text { arsip digital dokumen? }\end{array}$ & 15 & 0 & 0 \\
\hline 2. & Sebutkan pengertian dan definisi dari arsip digital? & 5 & 4 & 4 \\
\hline 3. & $\begin{array}{l}\text { Sebutkan tools atau komponen yang diperlukan untuk e-Arsip } \\
\text { dokumen berbasis teknologi informasi }\end{array}$ & 0 & 1 & 12 \\
\hline 4. & Sebutkan langkah untuk melakukan e-Arsip dokumen Dinas Luar & 0 & 0 & 13 \\
\hline 5. & $\begin{array}{l}\text { Apakah anda terbantu dengan penerapan e-Arsip dokumen pada } \\
\text { kegiatan dinas luar? }\end{array}$ & 0 & 0 & 13 \\
\hline & Total & 20 & 5 & 42 \\
\hline & Presentase & $\begin{array}{l}20 / 75^{*} \\
100 \%= \\
27,69 \%\end{array}$ & $\begin{array}{c}5 / 75^{*} \\
100 \%= \\
7,69 \%\end{array}$ & $\begin{array}{c}42 / 75 * 10 \\
0 \%= \\
64,62 \%\end{array}$ \\
\hline
\end{tabular}

Berdasarkan tabel diatas dapat diketahui bahwa banyak item pertanyaan yang tidak terjawab(kosong) total dari 15 peserta, hanya 20 pertanyaan dijawab dengan benar, 5 pertanyaan dijawab dengan salah dan sebagian besar tidak dijawab yaitu 42 kosong disini 
dapat kita simpulkan bahwa para peserta masih minim pengetahuannya tentang Arsip Digital.

Untuk item pertanyaan "Sebutkan pengertian arsip digital", dari jawaban kuesioner yang diolah bahwa dari 15 peserta hanya 5 orang jawabanya benar, 5 orang jawabannya salah dan 5 orang tak mengisi jawaban, jadi dapat disimpulkan sebahagian besar belum mengerti apa itu Arsip digital. Tetapi setelah dilakukan pelatihan Sebagian besar mengatakan mengerti dengan Arsip digital, ini menunjukan bahwa pelatihan tersebut berhasil

Selanjutnya untuk item pertanyaan "Sebutkan langkah untuk melakukan mengarsipkan dokumen", dari 15 peserta satupun tidak ada yang memberikan jawaban (kosong), kemudian setelah dilakukan pelatihan, hampir seluruh dapat menjawab dengan benar, jadi dapat disimpulkan ternyata dengan adanya pelatihan tentang e-Arsip dokumen yang sederhana ini akan membantu pegawai kantor Kesehatan Pelabuhan Pekanbaru menyelesaikan pekerjaan dengan waktu yang lebih efiisien, dimana dapat dilihat dari hasil olahan kuesioner di bawah ini.

Tabel 2. Hasil Rekapitulasi Kuesioner post test

\begin{tabular}{|l|l|c|c|c|}
\hline No & Item Pertanyaan & Benar & Salah & Kosong \\
\hline 1. & $\begin{array}{l}\text { Apa sebelumnya anda sudah pernah mendapatkan pelatihan e- } \\
\text { Arsip dokumen? }\end{array}$ & 15 & 0 & 0 \\
\hline 2. & $\begin{array}{l}\text { Sebutkan definisi dan pemanfaatan dari e-Arsip Dokumen yang } \\
\text { anda ketahui? }\end{array}$ & 15 & 0 & 0 \\
\hline 3. & $\begin{array}{l}\text { Sebutkan tools atau komponen yang diperlukan untuk e-Arsip } \\
\text { dokumen berbasis teknologi informasi }\end{array}$ & 15 & 0 & 0 \\
\hline 4. & Sebutkan langkah untuk melakukan e-Arsip dokumen Dinas Luar & 12 & 3 & 0 \\
\hline 5. & $\begin{array}{l}\text { Apakah anda terbantu dengan adanya aplikasi e-Arsip dalam } \\
\text { pekerjaan Dinas Luar? }\end{array}$ & 13 & 0 & 2 \\
\hline & Total & 63 & 3 & 2 \\
\hline & Presentase & $\begin{array}{c}70 / 75 * 1 \\
00 \%\end{array}$ & $\begin{array}{c}3 / 75 * 100 \% \\
=4,62 \%\end{array}$ & $\begin{array}{c}2 / 75 * 100 \% \\
=3,07 \%\end{array}$ \\
\hline
\end{tabular}

Jadi berdasarkan kedua tabel diatas dapat kita lihat meningkatnya kemampuan peserta setelah pelatihan diberikan.

Hasil dari pengabdian ini menunjukkan bahwa Pelatihan yang telah dilaksanakan tersebut berhasil dengan ukuran keberhasilan:

1. Peningkatan Pemahaman dari peserta terhadap pemanfaatan e-Arsip berbasis teknologi informasi dalam pekerjaan pada Kantor kesehatan Pelabuhan Pekanbaru. (dapat dilihat dari pengolahan data pretest dan postest).

2. Hasil pengolahan data kuisioner terhadap pemanfaatan e-Arsip dalam kegiatan dinas luar pada Kantor Kesehatan Pelabuhan Pekanbaru membantu pegawai dalam pengolahan data lebih efisien dan lebih baik dalam penyajian data informasi dinas luar(dapat dilihat pada pembahasan). 
Setelah pengabdian ini dilaksanakan dan data kuesioner sudah diolah pengetahuan dan keahlian peserta mengalami peningkatan terkait e-Arsip, dimana pengetahuan peserta naik secara signifikan sebesar $71,62 \%$ yaitu sebelum pelatihan $20,69 \%$ setelah pelatihan e-Arsip dokumen pada kegiatan dinas luar pada kantor Kesehatan pelabuhan pekanbaru dilaksanakan meningkat menjadi 92,31\%

\section{Kesimpulan}

Kesimpulan yang dapat ditarik penulis setelah melakukan kegiatan ini adalah Digital Enterpreneur masih menjadi sebuah informasi baru bagi peserta sehinnga peserta terlihat tertarik dan antusias untuk bertanya lebih dalam lagi ke pemateri terkait Digital Enterpreneur, selain itu beberapa peserta terlihat sudah memikirkan ide dan memilih jenis Digital Enterpreneur yang akan digelutinya

Saran dari beberapa peserta adalah kegiatan serupa perlu dilaksanakan kembali guna menggali lebih dalam lagi ilmu yang didapatkan dan bisa langsung mempraktekkannya nantinya.

\section{Ucapan Terima Kasih}

Penulis mengucapkan Terima kasih yang sebesar-besarnya kepada KKP Kelas II Pekanbaru dan seluruh sivitas beserta panitia yang telah berpartisipasi serta telah mendukung tim untuk dapat melaksanakan kegiatan ini dengan baik sejak awal hingga selesai. Selain itu kepada para peserta yang tidak bisa kami sebutkan satu persatu juga kami ucapkan terima kasih atas waktu dan kesempatan yang telah disediakan untuk kita, semoga apa yang telah kita sampaikan menjadi ilmu yang bermanfaat untuk pemateri dan untuk para peserta.

\section{Daftar Pustaka}

Crisna Adi Pranoto. (2020). Analisis Sistem Informasi Pengelolaan Arsip Vital Digital (earsip) di PT. Pertamina (persero). Vol 13 (1). Khazanah: Jurnal Pengembangan Kearsipan.

Dhefi Nur N. S. (2017). Penerapan sistem kearsipan elektronik sebagai determinan terhadap produktivitas kerja pegawai. Vol. 2 No. 2. Jurnal Pendidikan Manajemen Perkantoran.

Fajar Nyfantoro. (2019). Perkembangan Pengelolaan Arsip Elektronik di Indonesia: Tinjauan Pustaka Sistematis. Vol. 3 No. 1. 1-15. Diplomatika: Jurnal Kearsipan Terapan

Febriadi, Bayu. 2017. "Efisiensi Sistem Informasi berbasis Online Dalam pengumpulan RPKPS mata Kuliah Untuk Pengembangan Kompeteensi Program Studi" Vol 8, No. 1, Digital Zone, "Jurnal teknologi Informasio dan Komunikasi".

Florentina Esti Nilawati. (2019). Implementasi E-arsip Untuk Penyimpanan Dokumen Digital Pada PT BPD Jateng (Bank Jateng). Vol. 18 No. 4. 299-311. Tecno.COM. 
G. Farell, H. K. Saputra and I. Novid, "Rancang bangun sistem informasi pengarsipan surat menyurat (studi kasus fakultas teknik unp),"Jurnal Teknologi Informasi dan Pendidikan, vol. 11, no. 2, pp. 55-62, 2018.

Kementerian Pendidikan dan Kebudayaan. 2020. Pedoman Sistem Penjaminan Mutu Perguruan Tinggi, Jakarta.

Nailut Thoyibah, Sri Winiarti. 2014. Aplikasi bantu nilai indeks kinerja dosen (Studi kasus Di Fakultas Teknologi Industri UAD, Vol. 2 No. 1, Jurnal Sarjana Teknik Informatika).

Nyimas Sriwihajriyah, 2012, Perancangan aplikasi E-Profile berbasis online sebagai sarana informasi dosen pada stmik pusri Palembang, Jurnal Sistem Informasi (JSI), VOL. 4, NO. 1, April 2012.

Nugroho, A., "Rekayasa Perangkat Lunak Berorientasi Objek dengan Metode USDP", Andi, (2010).

Putranto, W. A. (2018). Pengelolaan Arsip Di Era Digital: Mempertimbangkan Kembali Sudut Pandang Pengguna. Diplomatika: Jurnal Kearsipan Terapan, 1(1), 1.https://doi.org/10.22146/diplomatika.28253.

Robby Yuli Endra. (2017). E-arsip Berbasis Image Arcchives Management Process Model Untuk Meningkatkan Pengelolaan Arsip. ISSN. 2087-2062. Jurnal Sistem Informasi dan Telematika.

Saraswati, E., "Sistem Informasi Akademik Berbasis Web Pada Sekolah Menengah Pertama Negeri 3 Pringkuku", Indonesian Journal On Networking and Security - IJNS, (Volume 2 No 4 - Oktober 2013, ISSN:2302-5700) 